本においてもオルソシステムの導入が増えてくると考え ている.

質問 畑川（大阪市大）：MTF を水ファントムを付加 した状態で撮影したのは，どういう理由か。

答 通常の使用状態に近い, 散乱線を含んだ状態での MTFを測定したかった.

買問 畑川：そうだとすれば，MTFが 1 から始まっ ているのはおかしいのではないか.

答 チャート上の 0 本のところを 1 として, わかりや すく表現した.

以上のような議論からもわかるように，MTF で評価す る場合には注意していただきたい.

画像理論- 2 （演題番号153～156）

小寺吉衛 (広島大学歯学部)

本セクションは, CRT 用フィルムの評価（演題153）, ROC と $18 \mathrm{AFC}$ の関係 (演題154), ディジタル系の MTF (演題155), 非相称系の NEQ（u）（演題156）と内容が 多岐にわたり，理論あるいはモデルと実験の関係を丁寧 に追跡したものが多く興味深かった。従来, 評価が単に 評価のための評価であった気がしていたが，本来，評価 はその結果を設計，あるいは開発にフィードバックしな くてはならない，今回の発表はそれぞれ非常に精度の良 い実験を行っており，その結果から，理論あるいはモデ ルとして面白いものが導かれていた。これらの考えを基 に，さらにもう一歩踏み込んで現場に環元できるような 方向に研究を進めていけば，先に挙げた意味での評価に つながるであろう。また，これは本学会の学問体系の一 つの方向を示しているのではなかろうか. 今後，このよ うな研究がさらに発展することを願う. 個々の演題に対 する感想は，以下の質疑応答の項で簡単に示す。

【演題153】質問 座長：各フィルムによって CRT の輝度とコントラストは調整したのか。

答 フィルム上で濃度とコントラストが一定になるよ うに調整したが，特性曲線の脚や肩の部分でいくらかず れが生じている。パターンを決める基準として SMPTE の信号を使って決めた。

座長 CRT 用フィルムの評価は増感紙フィルム系の 評価と異なり，新しい基準が必要だと思う。

質問 船越(大分医大)：フィルムごとにイメージャの 設定を行ったのか.

答 各フィルムごとにSMPTE を使って条件設定を 行った.

【演題154】吉田（岡山大医短）：ROC 曲線と18AFC
の関係式は理論ではなくモデルではないか。 答そうだと思う。

質問 座長：ガウス分布を仮定した関係式だと思う。 両者の結果の違いを観察者の心理的なもので説明してい たが，分布が仮定と一致しているかどうかは検討したの か.

答 確認していないが ROC 曲線の形からはほぼ等分 散だと思う。

【演題155】大塚（山口大）：現実問題としてフィルム に出力されたスリット像のうちどれがセンターアライメ ントでどれがシフトアライメントか決定するのが困難だ。

答 その通りだが，かなり近い值までは意外と簡単に 求まる。

質問 吉田：エイリアシングが非常に大きい場合，ナ イキスト周波数の 4 倍まで考慮して補正する必要がある のではないか.

答 その通りだ。

【演題156】座長：濃度の加法性を前提としてグラデ イエントの加法性を導き，その結果として MTF の加法 性を示唆しているが，これでよいのか.

答 非相称性の系の場合は, 大きなコントラストの被 写体については濃度が大きく異なるため非線形となり， 成り立たない。

質問 大塚：クロスオーバーがない場合はフロントと バックそれぞれのMTF を測って互いの奇与率で考慮す るという考えはだめだということか。

答 その通り。感度比ではできない.

\section{MR-5 撮像技術（演題番号157～161）}

太井 司（奈良県立医科大学附属病院） 撮影技術ということで, 既存の撮影法, 撮像法より優 れた画像，短縮された検査時間，より正確な測定法，そ して新なな物質の画像表現法などを検討された 5 題が発 表された。

演題157は, 脳幹部病変に対して, 脳幹長軸に直交する 断面で撮像する事により，断層面の再現性が良く，局所 解剖が詳細に表現されると報告している。

質問 川末 (昭和大学)：この発表の意義は。

答：症例が多く集まってきたので，脳幹部の撮影法と して統一するため.

この撮像断面などは，通常施行されている方法である が, 目的部位に応じた撮影断面や方法などは, 一刻も早 く統一されることが望まれる。ただ，この種の画像の比 較などをする場合にも，表やグラフにて表現できる手法 
を用いた技術学的検討方法にて評価してほしい.

演題158は, 3DFT 法を用いた T1 強調画像の脳下垂体 検査における最適撮像条件を求めたものである。Phantom および白質一死白質の $\mathrm{C} / \mathrm{N}, \mathrm{S} / \mathrm{N}$, 空間分解能上り検 討した結果, slice 厚： $3 \mathrm{~mm}$, matrix : $192 \times 256$, FOV : $15 \mathrm{~cm}$, flip angle $60^{\circ}$ が最も適し, 計測時間も 7 分に短 縮したと報告している。

質問 座長 : $T_{1}$ 強調画像として flip angle $60^{\circ}$ という のは.

答：Flip angle $90^{\circ}$ ではアーチファクトが多いが，600 はアーチファクトも少なく，信号強度も高い。

演題159は，慢性期解離性大動脈瘤において，二腔構 造, 解離口，血栓の MRI の描出能は，CT, DSAに比較 して同等，またはそれ以上である。また，MR CINEを 用いることによりさらに診断能が向上すると報告してい る.

質問 座長：DSA と比較して分解能はどうか.

答：分解能では劣るかもしれないが, 描出能など情報 量としては優れていると思われる.

演題 160 は, 肥大心の左室心筋重量を心電図非同期スキ ヤンより求め, 心電図同期スキャンや M-mode 心エコ一 図法より算出した值と比較している。電図同期スキャ ンとはほぼ相関するが，M-mode心エコー図法は，重量 を過大評価する傾向があったと報告している。

質問 座長：エコー法と比べて，検查手技などに要す る時間はどうか。

答：MRI では, 位置決めなどを含めると20分は要する ので，エコー法のほうが短時間である。しかし，本法で は Cineによる心筋の評価もできるので一連のルーチン ワークとしては有利であると考えている。

質問 座長：前回の発表では，心エコー図法から求め た左室心筋重量と相関していたが，今回相関しなかった のはなぜか。

答 正常心では，相関していたが，算出方法で回転棈 円体としているので，肥大心では必ずしも理想体となら ないため相関しないと考えられる。また，心エコー図法 から求める左室心筋重量の正確性も考え直さなければな らないかもしれない.

質問 中沢（鹿教湯病院）：MRI とエコー検査をルー チンで並行して行っているのか。

答 そこまでコントロールしていないが，お互いの测 定結果が出るまで公表しないようにしているので, 主観 の入っていない信憑性のあるデータであるといえる。

今後さらに研究を積まれて, 正確な左室心筋重量の測
定法を確立してほしい。

演題161は, diffusion imaging system を用いて拡散強 調画像から得られる生体内情報として，プロトンの動き や移動，拡散の異方性などを知る事ができ，さらにMRI の診断情報が拡大されたと報告している。

質問 座長：拡散の異方性について，3 軸同時に MPGパルスを付加すると問題があると発表されている. それでは，1軸ずつ単独に 3 方向に付加しないとわから ないのか.

答 3 方向それぞれ単独に付加しないとわからない. 臨床では事前に予測を立てて検査内容を絞っている。

質問 座長：拡散の速さの表現方法は.

答 水ファントムを同時にスキャンし，それょり速い， 遅いで評価している。

まだ撮像方法などに問題点が少しあるように思う。ま た，拡散速度などについての絶対評価は無理なのであろ うか. 今後, 臨床における適応なども加えて, 次なる報 告を期待したい.

以上総じて，撮影技術というのは，日常臨床に際し一 番身近な問題としてとらえるべき事柄である。そして， それらをいろいろ考案していくことがわれわれ技師の使 命であると思う。ここで発表されたように画像の再現性 や, MRI の有効な利用法, MRI を最大限に活用できる撮 像法, より正確な測定法, そして新しい画像表現法など について論じる事が MR 技術の発展につながり，ひいて は，いかなる施設に执いても，より良い画像を提供する ための統一された撮像法が普及され，確立されていくも のと思う。

\section{MR-6 コイル他（演題番号162～165）}

山田幸典（国立循環器病センター放射線診療部） 演題162-165はファントム, コイル, ${ }^{31} \mathrm{P},{ }^{1} \mathrm{H}$ スペクト ロスコピーと，身近なものから専門的なものまで多涠に わたるセクションであった、いつもながら会場からの質 問が少ないのは残念であった。

演題162は鹿教湯病院の石合らによる手近な液体で脳 組織の $\mathrm{T}_{1} ・ \mathrm{~T}_{2}$ 值の相関に近いファントムを作成し, 装置 の評価に用いたという演題であった．約50種の液体から 目的にかなう数種のものを見い出し経時変化をみたとい う前半に比べ, CNR・コントラスト分解能云々という後 半の展開は残念である。せっかく多くの試料を検討した のであるから，具体的に何々はどういう傾向があったと 提示すべきではないか。 また選び出した数種の試料につ いて混合・希积の程度に忍じ，どのように $\mathrm{T}_{1} ・ \mathrm{~T}_{2}$ 值が動 